\title{
Size-fractionated primary productivity and the phytoplankton-bacteria relationship in the Taiwan Strait
}

\author{
Bangqin Huang*, Huasheng Hong, Haili Wang \\ Research Laboratory of SEDC on Marine Ecological Environment / Environmental Science Research Center, \\ Xiamen University, Xiamen 361005 , China
}

\begin{abstract}
Size-fractionated phytoplankton biomass, primary productivity, photosynthetic dissolved organic carbon (PDOC), vertical distribution of pico-, nano-, and microphytoplankton, and the relationship with bacteria were studied in the Taiwan Strait during 2 cruises conducted in August 1994 and February-March 1995. Nanophytoplankton (3 to $20 \mu \mathrm{m}$ ) dominated the community in the northern Taiwan Strait (NTS) while picophytoplankton $(0.2$ to $3 \mu \mathrm{m})$ dominated in the southern Taiwan Strait (STS). Nanophytoplankton accounted for 60 and $57 \%$ of biomass, and 77 and $36 \%$ of productivity in summer and winter in the NTS, respectively. Picophytoplankton contributed to 54 and $63 \%$ of biomass, and 85 and $48 \%$ of productivity in summer and winter in the STS, respectively. The vertical distribution pattern in the Taiwan Strait consisted of microphytoplankton (20 to $200 \mu \mathrm{m}$ ) mainly at the surface, nanophytoplankton in the middle and picophytoplankton at the bottom of the euphotic zone. Regression analysis indicated that bacterial abundance and biomass were positively significantly correlated with phytoplankton biomass and productivity, respectively, implying that the phytoplankton was an important organic carbon source for supporting bacterial growth. All the results suggested that the microbial loop played an important role in carbon cycling in the study areas, especially in the STS. The factors controlling the size structure, PDOC and vertical distribution of picophytoplankton are discussed.
\end{abstract}

KEY WORDS: Size-fractionation - Phytoplankton - Biomass - Productivity - Bacteria - Microbial loop · Taiwan Strait

\section{INTRODUCTION}

Many physiological processes occurring in planktonic ecosystems are size dependent. Plankton ecologists have paid progressively more attention to the ecology of small cell size organisms in pelagic communities in aquatic ecosystems. Data on the size structure of phytoplankton biomass and productivity are documented in more and more studies in oceanic ecosystems (Malone 1980, Takahashi \& Bienfang 1983, Davis et al. 1985, Larry \& El-Sayed 1987, Chavez 1989, Ning et al, 1993, 1996, Hong \& Huang 1994, Liu et al. 1998). Nanophytoplankton accounts for a high proportion of the biomass and primary productivity in most phyto-

\footnotetext{
•E-mail: bqhuang@jingxian.xmu.edu.cn
}

plankton communities. With the development of new techniques, such as flow cytometry, electronic microscopy and epifluorescence microscopy, picophytoplankton (smaller than 2 to $3 \mu \mathrm{m}$ ) was found to be of considerable quantitative significance in many parts of the world's oceans (Platt et al. 1983, Stockner \& Antia 1986, Waterbury et al. 1986, Ray et al. 1989, Li 1994, Iriate \& Purdie 1995).

Bacteria are not only decomposers, but also producers (secondary producers); the microbial loop plays a very important role in the cycling of organic carbon in aquatic ecosystems (Anderson 1988, Bjørnsen et al. 1988, Jumars et al. 1989, Rieman et al. 1990, Middelboe et al. 1992). Phytoplankton and bacteria have a close relationship in aquatic ecosystems.

The present study focuses on the size-fractionated phytoplankton biomass and productivity, photosyn- 
thetic dissolved organic carbon, vertical distribution of 3 phytoplankton categories and the phytoplanktonbacteria relationship in the Taiwan Strait.

\section{DESCRIPTION OF STUDY AREAS}

The Taiwan Strait is a channel on the continental shelf between the East China Sea and the South China Sea (Fig. 1). With irregular bottom topography, the water in this region is mostly less than $100 \mathrm{~m}$ deep. The climate is affected by the subtropical monsoon, which comes from the southwest in summer and from the northeast in winter. Due to the corresponding NE-SW trend of the Strait and the mountains along the 2 sides, the 'Narrow Pipe Effect' is quite distinct, which leads to high wind speeds. Upwelling, resulting from the effect of the monsoon and its topography, is common in the Strait (Hong et al. 1991, Liang 1997). There are several currents such as the Zhejiang-Fujian Coastal Current, the Strait Warm Current and Kuroshio water in this region (Hong et al. 1991).

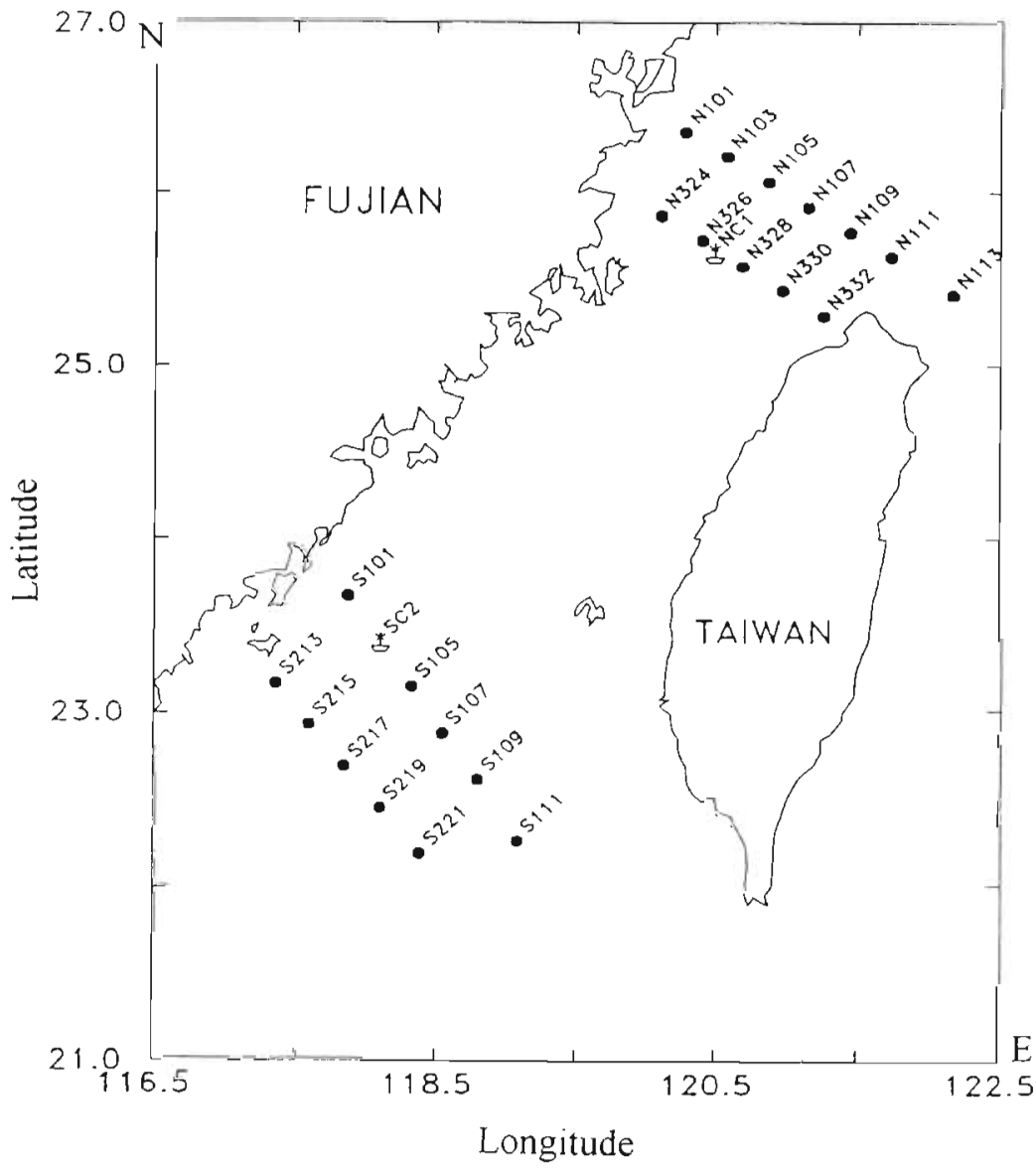

Fig. 1. Location and sampling stations in the Taiwan Strait

\section{METHODS}

Study site and sampling. Two cruises were carried out in the Taiwan Strait (21 to $27^{\circ} \mathrm{N}, 116.5$ to $122.5^{\circ} \mathrm{E}$ ) in August 1994 and February-March 1995. Fig. 1 shows the location of transects and 24 stations in the northern and southern Taiwan Strait. The CTD, chemical and biological oceanographic parameters were measured at all stations. Diurnal variations of size structure of chlorophyll a (chl a) were measured at Stn NC1 $\left(25^{\circ} 39.00^{\prime} \mathrm{N}\right.$, $120^{\circ} 29.10^{\prime} \mathrm{E}$ ) in February 1995, with a sampling interval of $6 \mathrm{~h}$. Water samples were taken with 51 Niskin bottles at depths of $0,10,20,30$, and $50 \mathrm{~m}$.

Size-fractionation. Size-fractionation of chl $a$ and photosynthetic rate were conducted according to the procedure reported by Wang et al. (1997). Phytoplankton in this present study were divided into 3 categories named micro- (20 to $200 \mu \mathrm{m})$, nano- (3 to $20 \mu \mathrm{m})$ and picophytoplankton $(0.2$ to $3 \mu \mathrm{m})$, water samples were fractionated by filtering with a $20 \mu \mathrm{m}$ mesh, 3 and $0.2 \mu \mathrm{m}$ Nuclepore fulters (Costar $\left.{ }^{(}\right)$.

Chlorophyll a. The determination of $\mathrm{chl}$ a was performed by fluorescence analysis (Parsons et al. 1984), with a slight modification. $150 \mathrm{ml}$ seawater sample was filtered under a pressure of less than $50 \mathrm{KPa}$, and extracted for $24 \mathrm{~h}$ in $90 \%$ acetone in $0^{\circ} \mathrm{C}$, and the fluorescent value was measured before and after acidifying in a Hitachi 850 Fluorospectrometer with the excitation and emission wavelength set at 430 and 670 $\mathrm{nm}$. Chl a could then be calculated from the formula,

$$
\begin{aligned}
\text { Chl } a= & F_{\mathrm{d}} \times[r /(r-1)] \\
& \times\left(R_{\mathrm{b}}-R_{\mathrm{a}}\right) \times\left(V_{1} / V_{2}\right)
\end{aligned}
$$

where Chl $a=$ concentration of $\mathrm{chl}$ a $(\mathrm{mg}$ $\left.\mathrm{m}^{-3}\right)_{i} F_{\mathrm{d}}=$ calibration factor $\left(\mathrm{mg} \mathrm{m}^{-3}\right) ; r=$ ratio of fluorescent value before and after acidifying for standard chl $a_{i} R_{\mathrm{b}}=$ fluorescent value before acidifying; $R_{\mathrm{a}}=$ fluorescent value after acidifying; $V_{1}=$ volume for extracting sample $(\mathrm{ml}) ; V_{2}=$ volume of water sample filtering.

$F_{\mathrm{d}}$ and $r$ could be measured from standard pure chl a

$$
F_{\mathrm{d}}=\mathrm{CHLA} \mathrm{STD}_{\mathrm{ST}} /\left(R_{1}-R_{2}\right) \quad r=R_{1} / R_{2}
$$

where CHLA ${ }_{\text {STD }}=$ concentration $($ known $)$ of standard pure chl a $\left(\mathrm{mg} \mathrm{m}^{-3}\right) ; R_{1}=$ fluorescent value before acidifying: $R_{2}=$ fluorescent value after acidifying.

Photosynthetic rate. Phytoplankton photosynthetic rate was measured by the ${ }^{14} \mathrm{C}$ method based on Parsons et al. (1984). 
$120 \mathrm{ml}$ seawater sample was incubated after the addition of ${ }^{14} \mathrm{C}-\mathrm{NaHCO}_{3}(185 \mathrm{KBq})$; the incubation was carried out on deck for $3 \mathrm{~h}$ with running seawater, which provided temperature control. At the end of incubation, the samples were filtered onto Nuclepore filters $\left(\operatorname{Costar}^{\oplus}\right)$ according to the size fractionation above, and the filters were fumed with concentrated hydrochloric acid to remove inorganic ${ }^{14} \mathrm{C}$, then dried and stored in darkness, scintillation cocktail (Optiphase 'Hisafe') was added, and the radioactivity was measured using a Pharmacia-LKB 1409 liquid scintillation counter.

Photosynthetic dissolved organic carbon. Photosynthetic dissolved organic carbon was measured using the acid bubbling method (Wood \& Vaalen 1990, Jiao \& Wang 1994), with slight modifications: $5 \mathrm{ml}$ filtrate (passing through $0.2 \mu \mathrm{m}$ filter) of incubation samples, adjusted to $\mathrm{pH}<1$ with $1: 1$ (v/v) hydrochloric acid $(\mathrm{HCl})$ and distilled water, was bubbled with nitrogen $\left(\mathrm{N}_{2}\right)$ for 30 to $45 \mathrm{~min}$ at a speed of $300 \mathrm{ml} \mathrm{min}^{-1}$, then adjusted to $\mathrm{pH}=7$ with $1 \mathrm{~N}$ sodium hydroxide and bubbled again with carbon dioxide $\left(\mathrm{CO}_{2}\right)$ for 15 to 20 min, then $5 \mathrm{ml}$ modified scintillation cocktail (8:2 [v/v] scintillation cocktail [Optiphase 'Hisafe'] and Triton X-100) was added.

Bacterial biomass. Bacterial biomass was calculated from bacterial abundance, which was measured with the AODC method (Parsons et al. 1984). Bacterial volume was measured by scanning electronic microscopy and converted to carbon biomass assuming a transfer factor of $0.121 \mathrm{pg} \mathrm{C} \mathrm{mm}^{-3}$ (Watson et al. 1977).

Bacterial productivity. Bacterial productivity was determined by thymidine incorporation based on the method of Fuhrman \& Azam (1982). 9.25 KBq (Methyl${ }^{3} \mathrm{H}$ )-thymidine was added to $20 \mathrm{ml}$ samples. Triplicate samples and controls (formalin-killed, final conc. $0.5 \%$ ) were incubated at in situ temperature in the dark for $30 \mathrm{~min}$, the incubations were stopped with formalin (final conc. $0.5 \%$ ). To each $20 \mathrm{ml}$ sample and control, an equal volume of ice-cold $10 \%$ (wt/v) TCA was added and the mixtures were kept on ice for
10 min. The TCA-insoluble fraction was collected by filtering the sample through a $0.2 \mu \mathrm{m}$ Nuclepore filter $(25 \mathrm{~mm})\left(\operatorname{Costar}^{(8)}\right)$. The filters were rinsed 5 times with $1 \mathrm{ml}$ of ice-cold $5 \%$ (wt/v) TCA and then dried, dissolved in $10 \mathrm{ml}$ scintillation cocktail (Optiphase 'Hisafe'), the radioactivity was measured using a Pharmacia-LKB 1409 liquid scintillation counter.

Bacterial heterotrophic activity. Bacterial heterotrophic activity was measured by radio-labeled D-Glucose uptake (Parsons \& Strickland 1962, Wright \& Hobbie 1966): $183 \mathrm{KBq}{ }^{14} \mathrm{C}$-D-glucose was added to $125 \mathrm{ml}$ water sample and incubated at in situ temperature in the dark for $1 \mathrm{~h}$; it was then filtered under a pressure of less than $50 \mathrm{KPa}$, filters were dried and radioactivity was measured using a Pharmacia-LKB 1409 liquid scintillation counter.

\section{RESULTS}

\section{Size structure of biomass and productivity of phytoplankton}

Nanophytoplankton dominated the phytoplankton biomass ( $\mathrm{chl}$ a) in the northern Taiwan Strait (NTS) while picophytoplankton were dominant in the southern Taiwan Strait (STS) in both summer and winter (Table 1). Nanophytoplankton accounted for 60 and $57 \%$ of biomass in summer and winter in the NTS, respectively, and picophytoplankton constituted 54 and $63 \%$ of biomass in summer and winter in the STS, respectively.

Size structure of primary productivity is similar to that of biomass (Table 2). Nanophytoplankton and picophytoplankton dominated primary productivity in the NTS and the STS, respectively; however, their dominance decreased in winter compared to that in summer, with nanophytoplankton accounting for only $36 \%$ of the total primary productivity in winter, as opposed to $77 \%$ in summer in the NTS, and picophytoplankton only constituting $48 \%$ of total primary productivity in winter, while this was $85 \%$ in summer in the STS.

Table 1. Size-fractionated biomass (average chl $\mathrm{a}_{1} \mathrm{mg} \mathrm{m}^{-3}$ ) and percentage of 3 sizes of phytoplankton (average \% and standard deviation, SD) in the Taiwan Strait

\begin{tabular}{|c|c|c|c|c|c|c|c|c|c|}
\hline \multirow[t]{2}{*}{ Season } & \multirow[t]{2}{*}{ Size } & \multicolumn{4}{|c|}{ Northern Taiwan Strait } & \multicolumn{4}{|c|}{ Southern Taiwan Strait } \\
\hline & & $\begin{array}{c}\text { Average } \\
\text { chl a }\end{array}$ & $\begin{array}{c}\text { Average } \\
\%\end{array}$ & $\mathrm{SD}$ & $\mathrm{n}$ & $\begin{array}{c}\text { Average } \\
\text { chl } a\end{array}$ & $\begin{array}{c}\text { Average } \\
\%\end{array}$ & $\mathrm{SD}$ & $\mathrm{n}$ \\
\hline \multirow[t]{3}{*}{ Summer } & Micro- & 0.135 & 20 & 17 & 11 & 0.160 & 22 & 22 & 6 \\
\hline & Nano- & 0.379 & 60 & 15 & 11 & 0.157 & 24 & 19 & 6 \\
\hline & Pico- & 0.115 & 20 & 18 & 11 & 0.448 & 54 & 22 & 6 \\
\hline \multirow[t]{3}{*}{ Winter } & Micro- & 0.227 & 26 & 21 & 27 & 0.043 & 5 & 5 & 14 \\
\hline & Nano- & 0.446 & 57 & 16 & 27 & 0.301 & 32 & 10 & 14 \\
\hline & Pico- & 0.137 & 17 & 14 & 27 & 0.599 & 63 & 11 & 14 \\
\hline
\end{tabular}


Table 2. Size-fractionated primary productivity (average $P R, m g C m^{-3} h^{-1}$ ) and percentage of 3 sizes of phytoplankton (average \% and standard deviation, SD) in the Taiwan Strait

\begin{tabular}{|c|c|c|c|c|c|c|c|c|c|}
\hline \multirow[t]{2}{*}{ Season } & \multirow[t]{2}{*}{ Size } & \multicolumn{4}{|c|}{ Northern Taiwan Strait } & \multicolumn{4}{|c|}{ Southern Taiwan Strait } \\
\hline & & $\begin{array}{c}\text { Average } \\
\text { PR }\end{array}$ & $\begin{array}{c}\text { Average } \\
\%\end{array}$ & SD & $\mathrm{n}$ & $\begin{array}{c}\text { Average } \\
\text { PR }\end{array}$ & $\begin{array}{c}\text { Average } \\
\%\end{array}$ & $\mathrm{SD}$ & $\mathrm{n}$ \\
\hline \multirow[t]{3}{*}{ Summer } & Micro- & 0.185 & 20 & 36 & 8 & 0.062 & 6 & 3 & 6 \\
\hline & Nano- & 1.166 & 77 & 39 & 8 & 0.108 & 9 & 7 & 6 \\
\hline & Pico- & 0.038 & 3 & 6 & 8 & 0.889 & 85 & 5 & 6 \\
\hline \multirow[t]{3}{*}{ Winter } & Micro- & 0.307 & 34 & 22 & 6 & 0.161 & 23 & 18 & 8 \\
\hline & Nano- & 0.383 & 36 & 20 & 6 & 0.178 & 29 & 6 & 8 \\
\hline & Pico- & 0.302 & 30 & 24 & 6 & 0.242 & 48 & 19 & 8 \\
\hline
\end{tabular}

Diurnal variation of size-fractionated biomass varied with depth (Fig. 2). Microphytoplankton changed sharply in the upper $30 \mathrm{~m}$. It showed high concentration in the day and low value in the night at depths of 0,10 , and $20 \mathrm{~m}$, whereas it showed low concentration in the day and high value in the night at a depth of $30 \mathrm{~m}$, and slight variation at a depth of $50 \mathrm{~m}$. The vertical migration and grazing pressure of mesozooplankton is a probable cause of this variation.

\section{Photosynthetic dissolved organic carbon}

The percentage of photosynthetic dissolved organic carbon (PDOC) was measured at Stns NC1 and S213 in February 1995. The average PDOC was $24.8 \%$. Total photosynthetic rate (TPR) was the sum of photosynthetic particulate organic carbon (PPOC) and PDOC (Table 3).

\section{Vertical distribution of micro-, nano- and picophytoplankton}

There were different vertical distribution patterns between summer and winter. In summer, the vertical distribution pattern of the 3 size fractions of phytoplankton was significantly different within the euphotic zone. For example, at Stn N330, the high picophytoplankton biomass was at depths of 20 and $35 \mathrm{~m}$, while the high nanophytoplankton biomass was at $20 \mathrm{~m}$ and that of microphytoplankton at 0 and $20 \mathrm{~m}$ (Fig. 3). The distribution pattern showed microphytoplankton in surface and near-surface waters, nanophytoplankton in the middle and picophytoplankton at the bottom of

Fig. 2. Diumal variation of size-fractionated biomass (ch] a) in winter in the Taiwan Strait at Stn NC1. MICRO: microphytoplankton; NANO: nanophytoplankton; PICO: picophytoplankton
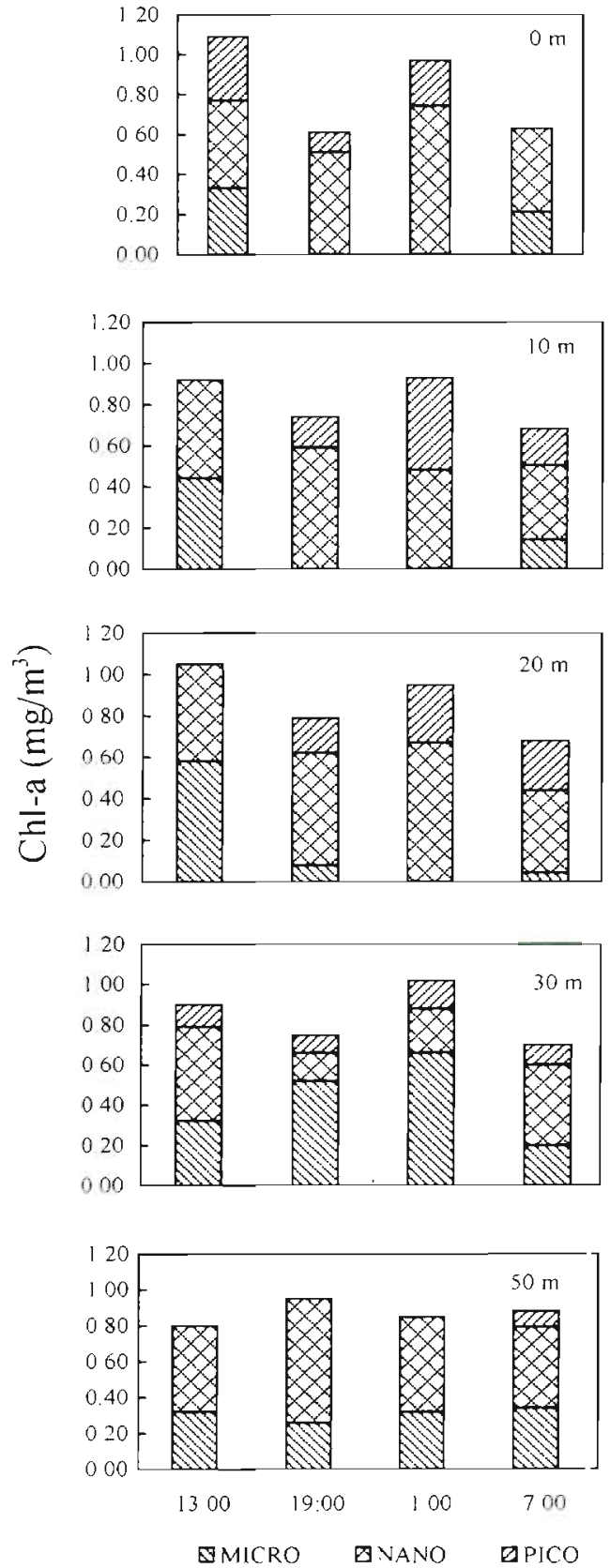
Table 3. Photosynthetic particulate organic carbon (PPOC), photosynthetic dissolved organic carbon (PDOC), total photosynthetic rate (TPR) and percentage of PDOC in the Taiwan Strait

\begin{tabular}{|cccccc|}
\hline Station & $\begin{array}{c}\text { Relative Irradiation } \\
\left(\mathrm{mg} \mathrm{m}^{-3} \mathrm{~h}^{-1}\right)\end{array}$ & $\begin{array}{c}\text { PPOC } \\
\left(\% \mathrm{I}_{0}\right)\end{array}$ & $\begin{array}{c}\text { PDOC } \\
\left(\mathrm{mg} \mathrm{m}^{-3} \mathrm{~h}^{-1}\right)\end{array}$ & $\begin{array}{c}\text { TPR } \\
\left(\mathrm{mg} \mathrm{m}^{-3} \mathrm{~h}^{-1}\right)\end{array}$ & $\begin{array}{c}\text { PDOC } \\
(\%)\end{array}$ \\
\hline \multirow{3}{*}{$\mathrm{NC1}$} & 100 & 1.012 & 0.283 & 1.295 & 21.9 \\
& 10 & 0.509 & 0.180 & 0.689 & 26.1 \\
$\mathrm{~S} 213$ & 1 & 0.169 & 0.083 & 0.252 & 32.9 \\
& 100 & 1.459 & 0.533 & 1.992 & 26.8 \\
& 10 & 0.934 & 0.181 & 1.115 & 16.2 \\
\hline
\end{tabular}

the euphotic zone, which was $36 \mathrm{~m}$ at this station. In addition, the contribution of picophytoplankton to total phytoplankton (in biomass) also increased with depth from the surface to the bottom (Table 4). However, in winter, the vertical distribution pattern of the 3 size fractions of phytoplankton was different from that in summer. For example, the higher microphytoplankton occurred at the bottom, the picophytoplankton was mainly at depths of 10 to $20 \mathrm{~m}$ and the nanophytoplankton was uniformly

Table 4. Contribution of picophytoplankton to total phytoplankton (in biomass) in summer $(\%)$

\begin{tabular}{|lrrrrr|}
\hline Depth $(\mathrm{m})$ & 0 & 10 & 20 & 35 & 40 \\
\hline Stn N330 & 30 & & 31 & 54 & \\
Stn NC1 & 0 & & 40 & & 16 \\
Stn S215 & 75 & 77 & 82 & & \\
\hline
\end{tabular}
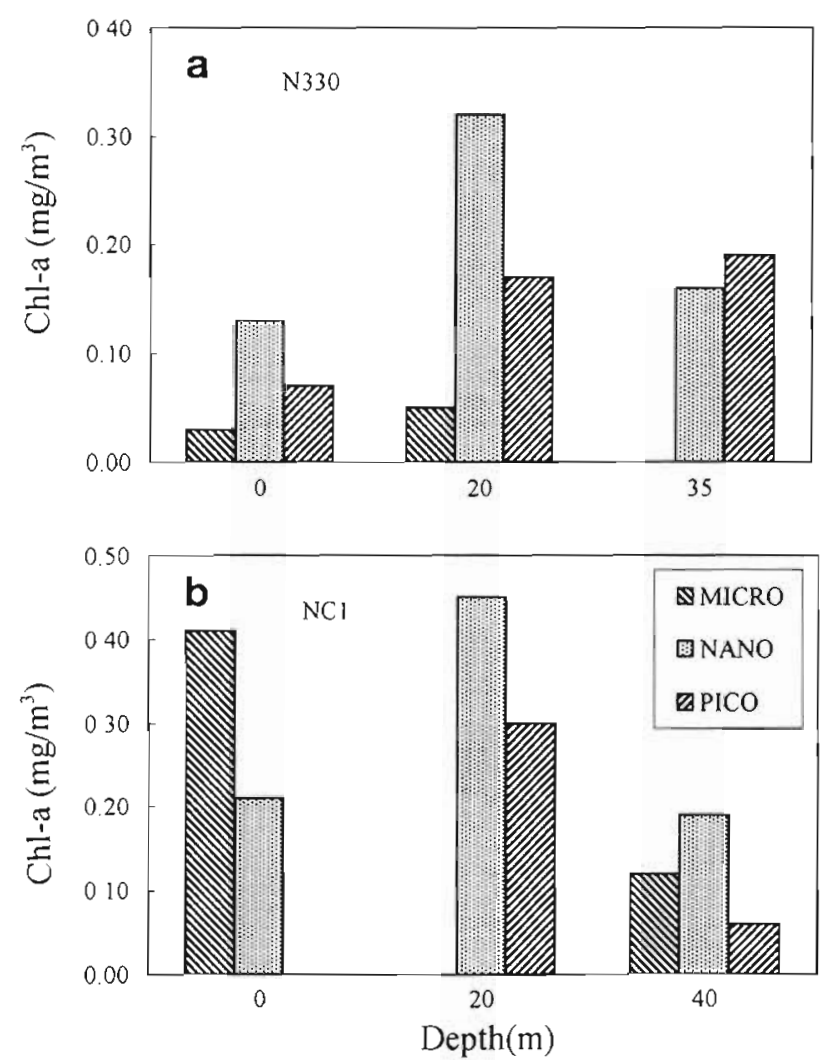

Fig. 3. Vertical distribution of size-fractionated biomass in summer (a) at Stn N330 and (b) at Stn NC1 (see Fig. 2 for abbreviations) distributed (Fig. 4). The pattern during winter may be due to strong mixing of seawaters.

\section{Phytoplankton-bacteria relationship}

The results showed that bacterial abundance (TB, $\times 10^{6}$ ind $\mathrm{ml}^{-1}$ ) was positively significantly correlated with phytoplankton biomass (chl a, $\mathrm{mg} \mathrm{m}^{-3}$ ) (Fig. 5),

$\mathrm{TB}=1.201+0.827$ Chl $a \quad(\mathrm{p}<0.01, r=0.502, \mathrm{n}=68)$

Bacterial productivity (BP, mg $\mathrm{C}^{-3} \mathrm{~d}^{-1}$ ) was positively significantly correlated with photosynthetic rate (PR, mg C m $\mathrm{m}^{-3} \mathrm{~d}^{-1}$ ) (Fig. 6),

$$
\mathrm{BP}=0.93+0.106 \mathrm{PR} \quad(\mathrm{p}<0.01, r=0.655, \mathrm{n}=20)
$$
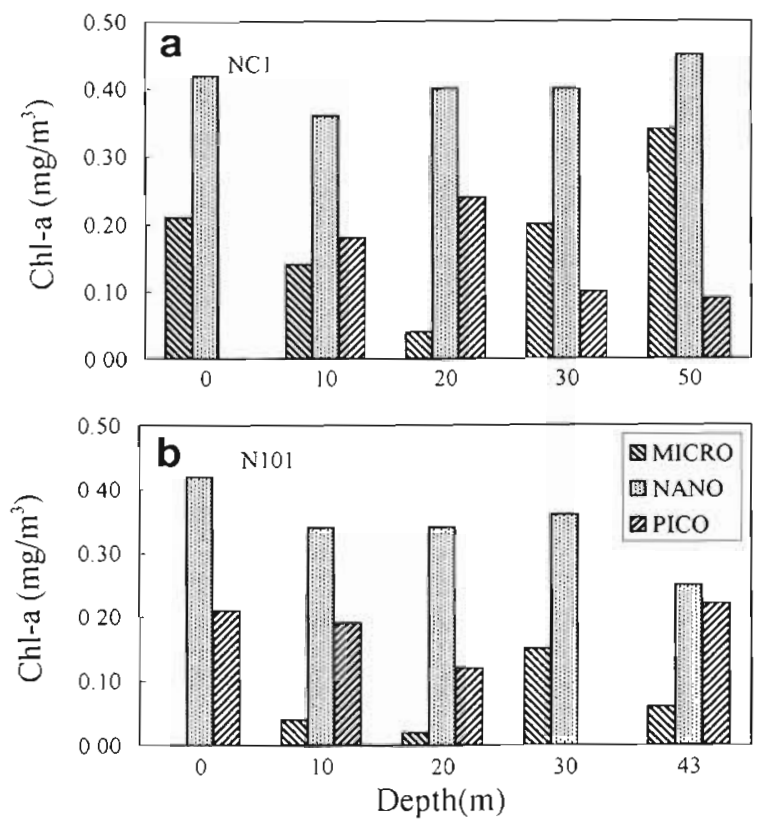

Fig. 4. Vertical distribution of size-fractionated biomass in winter (a) at Stn NC1 and (b) at Stn N101 (see Fig. 2 for abbreviations) 


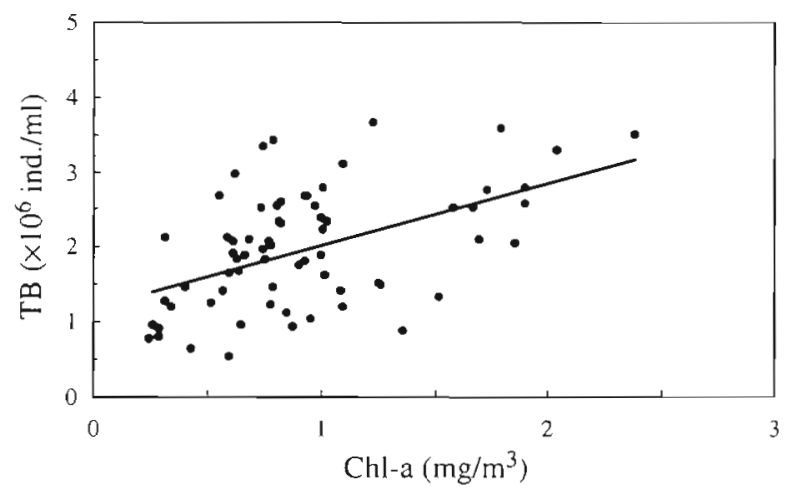

Fig. 5. Relationship between bacterial abundance (TB) and chl a biomass (Chl-a)

Therefore, TB and BP coupled very closely with primary processes (phytoplankton biomass and primary productivity), implying that phytoplankton was an important organic carbon source for supporting the growth of bacteria. Bacterial heterotrophic activity (BHA, mg C m $\mathrm{m}^{-3} \mathrm{~d}^{-1}$ ) positively correlated with PDOC (mg C m${ }^{-3} \mathrm{~d}^{-1}$ ) (Fig. 7),

$$
\mathrm{BHA}=3.395+0.186 \mathrm{PDOC} \quad(\mathrm{r}=0.555, \mathrm{n}=8)
$$

implying that photosynthetic product (especially PDOC) could be utilized by bacteria.

\section{DISCUSSION}

\section{Factors controlling the size structure of phytoplankton and PDOC}

The data in this study showed that phytoplankton size structure had remarkable differences between the the NTS and the STS $i$ picophytoplankton dominated in the STS while nanophytoplankton prevailed in the NTS.

It is known that the size structure of phytoplankton is correlated with latitude (mainly temperature), light

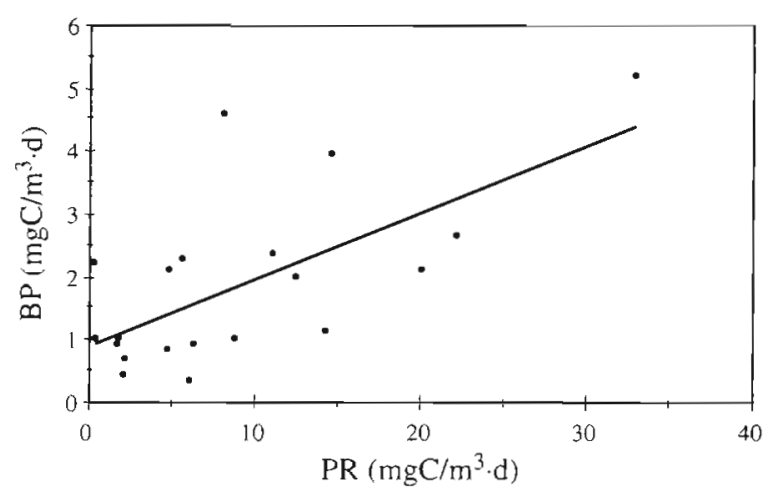

Fig. 6. Relationship between bacterial production (BP) and primary productivity (PR)

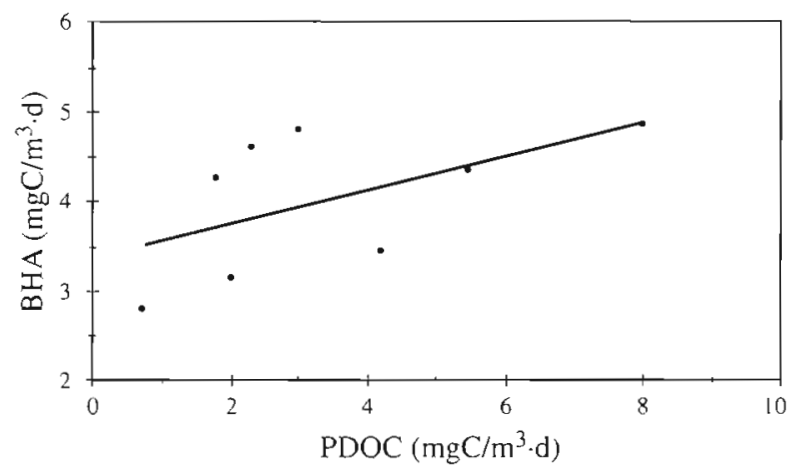

Fig. 7. Relationship between bacterial heterotrophic activity (BHA) and photosynthetic dissolved organic carbon (PDOC)

intensity and nutrient level. Murphy \& Haugen (1985) concluded that microphytoplankton abundance increased while picophytoplankton decreased as latitude increased. In addition, the nutrient level also affected the size structure of phytoplankton; as we know that the Michelis-Menten constant of phytoplankton depends on cell size, the smaller the cell is, the lower the constant. Thus, picophytoplankton should dominate the phytoplankton community in oligotrophic waters.

Based on the Michaelis-Menten constant $(K)$ measured by Eppley et al. (as cited in Chen \& Qian 1992) for microphytoplankton, $K$ of phosphate and nitrate was 0.12 to $0.55 \mu \mathrm{mol} \mathrm{l}^{-1}$ and 0.1 to $6.5 \mu \mathrm{mol} \mathrm{l}^{-1}$, respectively. The phosphate concentration was smaller than the $K$ of microphytoplankton in both the NTS and the STS in summer (Table 5), so it must limit their growth. The average phosphate concentration in the surface water was only $0.07 \mu \mathrm{mol} \mathrm{l}^{-1}$ in the STS, which may limit the growth of nanophytoplankton, therefore, picophytoplankton predominated the community. Nitrate could not limit the 3 size fractions of phytoplankton because its concentration was higher than the $K$ of nitrate uptake in the study area. Data showed that N/P ratios were higher than the Redfield value (24 for yearly average and 46 for summer average in

Table 5. Nutrient level of surface waters in the Taiwan Strait $\left(\mu \mathrm{mol} \mathrm{l}{ }^{1}\right.$ ) (Wu et al. $\left.1997 \mathrm{a}, \mathrm{b}\right)$. NTS: northern Taiwan Strait STS: southern Taiwan Strait

\begin{tabular}{|lccc|}
\hline Location & Nutrients & Summer & Winter \\
\hline NTS & Phosphate & 0.12 & 0.42 \\
& Nitrate & 4.75 & 9.15 \\
& n & 12 & 11 \\
STS & Phosphate & 0.07 & 0.18 \\
& Nitrate & 5.70 & 2.55 \\
& n & 12 & 7 \\
\hline
\end{tabular}


the surface water), phosphate played a more important role than nitrate in controlling phytoplankton growth in this region (Wu et al. $1997 \mathrm{a}, \mathrm{b}$ ).

It has been well recognized that healthy algal cells released PDOC during photosynthesis, which could support bacterial growth (Wood \& Vaalen 1990, Jiao \& Wang 1994). The PDOC yield was affected by many external factors such as light intensity, temperature and nutrient status. Among these, light intensity had the most significant effect. The data showed that PDOC percentage increased when being exposed to extreme conditions such as low light intensity ( $1 \%$ of incident light $\left(I_{0}\right)$ in NC1) (Table 3) (Zlotnik \& Bubinsky 1989 , Jiao \& Wang 1994). Bjørnsen (1988) pointed out that algae could passively release DOC, which is uncorrelated with the photosynthetic process, but positively correlated with biomass and ratio of the surface area versus the volume of alga, therefore, the smaller the alga, the higher the PDOC; more PDOC would flow to the microbial loop if nano- and picophytoplankton dominated the phytoplankton community. Anderson (1988) concluded that the microbial loop played a much more significant role in pico- and nanophytoplankton-dominated communities. However, Baines \& Pace (1991) summarized results from an in situ investigation and pointed out that the PDOC yield was not mainly affected by algal biomass, especially in coastal. areas and estuaries, and that PDOC was positively lineally correlated with primary productivity. PDOC was quite high ( $24.8 \%$ on average) in the Taiwan Strait (Table 6), which might be due to the dominance of nano- and picophytoplankton in the study area, especially in the STS where picophytoplankton predominated significantly in biomass and productivity.

\section{Factors affecting vertical distribution of picophytoplankton}

The result in this study indicated that the high picophytoplankton occurred at the bottom or near the bottom of the euphotic zone. This is consistent with the results reported by Platt et al. (1983) and Li (1994), but it is different from those reported by Happey-Wood (1993), Waterbury et al. (1986) and Joint (1989), who observed that the picophytoplankton maximum was in surface and near-surface waters. Sournia (1982) and Glover et al. (1985) concluded that the picophytoplankton belonged to 'shade flora' and were most abundant at the bottom of the euphotic zone. Based on research of vertical distribution and diurnal variation of picophytoplankton, Stockner \& Antia (1986) concluded that the contribution of picophytoplankton to total phytoplankton tended to increase with the depth of the euphotic zone, and that picophytoplankton had the ability to absorb blue-green light for phototsynthesis. The present study supported the result that picophytoplankton belonged to 'shade flora'.

Besides light intensity, the vertical distribution of picophytoplankton was also affected by the thermocline. For example, there was a thermocline between 20 and $40 \mathrm{~m}$ in Stn NC1 in summer (Fig. 8), and the picophytoplankton biomass above the thermocline was 5 times the biomass beneath it $(40 \mathrm{~m})$. This is similar to the result reported by Ning \& Vaulot (1991) in the Yangtze River estuary.

\section{Phytoplankton-bacteria interaction in coastal ocean}

Nutrient levels can control the community structure of microorganisms. Generally, phytoplankton are the main contributors to living biomass in eutrophic areas,

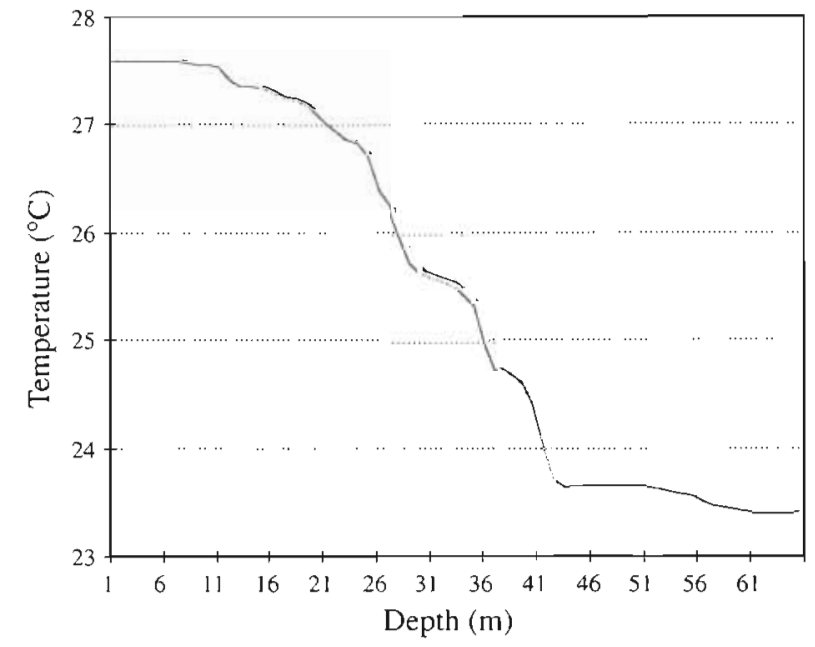

Fig. 8. Profile of temperature at Stn $\mathrm{NCl}$ in summer 
but bacteria and zooplankton dominate living biomass in oligotrophic waters (Dorth \& Packard 1989). For instance, bacteria contributed $70 \%$ of planktonic carbon biomass in the oligotrophic Sargasso Sea (Fuhrman et al. 1989). Phytoplankton contributed about $27 \%$ POC, and bacteria only $2.5 \%$ in the Taiwan Strait. This was due to the relatively high nutrient levels, which resulted from upwelling (Liang 1997), the coastal current and land inputs in the Strait (Wu et al. 1997a,b); therefore, phytoplankton dominated the living biomass. Bacterial productivity contributed 5 to $52 \%$ (22\% on average) of primary productivity in the Taiwan Strait, which was double that of the East China Sea and the northeast waters of Taiwan (Liu pers. comm. 1995). If bacterial growth efficiency was 13 to $24 \%$ (Linley \& Newell 1984), then primary production (organic carbon) in the euphotic zone was almost utilized by bacteria. On the other hand, organic carbon from primary production could cover 60 to $100 \%$ bacterial growth, this result was similar to others in coastal oceans (Billen \& Fontiguy 1987, Lancelot \& Mathot 1987). As bacteria consumed most of the primary organic carbon, there was small output of organic carbon in both vertical and horizontal directions in the Taiwan Strait and shelf of the East China Sea, which was similar to the result of the Atlantic Ocean SEEP-II plan (Biscaye et al. 1994).

\section{The importance of the microbial loop in the Taiwan Strait}

The ecological significance of bacteria and protozoa has been recognized. Bacteria have played an important role in aquatic ecosystems since 1980 (Hobbie et al. 1977. Fuhrman \& Azam 1980). It was estimated that some 10 to $57 \%$ photosynthetic organic carbon was released as a dissolved form (called PDOC) (Larsson \& Hagström 1982, Jiao \& Wang 1994). PDOC could be utilized by bacteria, and the latter was grazed on protozoa (ciliates and flagellates), which made an energy connection between bacteria and zooplankton; this energy flowing structure (PDOC $\rightarrow$ bacteria $\rightarrow$ protozoa $\rightarrow$ zooplankton) was called the microbial loop (Azam et al. 1983).

In the Taiwan Strait, the significant dominance of pico- and nanophytoplankton, the high PDOC yield and the bacterial productivity suggested that the microbial loop would play an important role in organic carbon transformation in this region. However, the study on the microbial loop had many limits. It is still uncertain whether the microbial loop was a sink or a link in carbon cycling (Ducklow et al. 1986, Sherr et al. 1987). In the Taiwan Strait, data on protozoa (ciliates and flagellates) are needed to estimate their role in organic carbon transformation and size grazing pressure of zooplankton on phytoplankton.
Acknowledgements. The authors would like to thank Prof. Dana Kester of Graduate School of Oceanography, University of Rhode Island for his helpful comments on the manuscript. We also thank the captain and crews of RV 'Yanping' No. 2, who made concerted efforts during sampling, and Prof. Hongxing Liang for CTD data, Prof. Liyun Wu for nutrient data, and Prof. Tianling Zheng for bacterial data. This work was supported by the grant of China NSF (No. 49636220 , 49776308), National Education Ministry of China and Fujian Commission of Science and Technology.

\section{LITERATURE CITED}

Anderson $\mathrm{P}$ (1988) The quantitative importance of the 'microbial loop' in the marine pelagic: a case study from the North Bering/Chuckchi Seas. Arch Hydrobiol Beih Ergeb Limnol 31:243-251

Azam F, Fenchel T, Field JG, Gray JS, Meyen-Reil LA, Thingstad $F(1983)$ The ecological role of water column microbes in the sea. Mar Ecol Prog Ser 10:257-263

Baines SB, Pace ML (1991) The production of dissolved organic matter by phytoplankton and its importance to bacteria: patterns across marine and freshwater system. Limnol Oceanogr 36:1078-1090

Baretta-Bekker JG, Riemann B, Baretta JW, Rasmussen EK (1994) Testing the microbial loop conception by comparing mesocosm data with results from a dynamical simulation model. Mar Ecol Prog Ser 106:187-198

Billen G, Fontiguy A (1987) Dynamics of a Phaeocystis dominated spring bloom in Belgian coastal waters. II. Bacterioplankton dynamics. Mar Ecol Prog Ser 37:249-257

Biscaye PE, Flagg CN, Falkowski PG (1994) The shelf-edge exchanges processes experiment, SEEP-II: an introduction to hypotheses, results and conclusions. Deep-Sea Res 41 : $231-252$

Bjørnsen PK (1988) Phytoplankton release of organic matter: why do healthy cells do it? Limnol Oceanogr 33:151-154

Bjørnsen PK, Rieman B, Horsted SJ, Nielsen TG, Pock-Sten J (1988) Trophic interactions between heterotrophic nanoflagellates and bacterioplankton in manipulated seawater enclosures. Limnol Oceanogr 33:409-420

Chavez FP (1989) Size distribution of phytoplankton in the central and eastern tropical Pacific. Global Biogeochem Cycles 3:27-35

Chen HQ, Qian SB (1992) Studies on nano- and picophytoplankton in coast of Qingdao, China. Acta Oceanol Sinica $14(3): 105-113$

Davis PG, Caron DA, Johnson PW, Sieburth JM (1985) Phototrophic and apochlorotic components of picoplankton and nanoplankton in the north Atlantic: geographic, vertical, seasonal and diel distributions. Mar Ecol Prog Ser 21:15-26

Dorth Q, Packard TT (1989) Difference in biomass structure between oligotrophic and eutrophic marine ecosystems. Deep-Sea Res 36:223-240

Ducklow HW, Purdie DA, William PJL, Davies JM (1986) Bacterioplankton: a sink for carbon in a coastal marine plankton community. Science 232:865-867

Fuhrman J, Azam. F (1980) Bacterioplankton secondary production estimates for coastal waters off British Columbia, Antarctica and California. Appl Environ Microb 39: 1085-1095

Fuhrman JA, Azam F (1982) Thymidine incorporation as a measure of heterotrophic bacterioplanktor production in marine surface waters: evaluation and field result. Mar Biol 16:109-120 
Fuhrman JA, Sleeter TD, Carlson CA, Procton LM (1989) Dominance of bacterial biomass in the Sargasso Sea and its ecological implications. Mar Ecol Prog Ser 57:207-217

Glover HE, Smith AE, Sharpiro L (1985) Diurnal variations in photosynthetic rates: comparison of ultraphytoplankton with a larger phytoplanktan size fraction. J Plankton Res $7: 519-535$

Happey-Wood CM (1993) Diurnal and seasonal variation in the contributions of autotrophic pico-, nano- and microplankton to the primary production of an upland lake. J Plankton Res 15:125-159

Hobbie JE, Daley RJ, Jaspers AS (1977) Use of nucleopore filters for counting bacteria by epifluorescence. Appl Environ Microb 33:1225-1228

Hong HS, Huang BQ (1994) Size-fractionated phytoplankton biomass and productivity in Xiamen harbour in autumn. J Xiamen Uni (Natural Science) 33(suppl):12-16

Hong HS, Qiu SY, Ruan WQ, Hong GC (eds) (1991) MinnanTaiwan Bank fishing ground upwelling ecosystem study Science Press, Beijing, p 1-18

Iriarte A, Purdie DA (1995) Size distribution of chlorophyll a biomass and primary production in a temperate estuary (Southampton Water): the contribution of photosynthetic picoplankton. Mar Ecol Prog Ser 115:283-297

Jiao NZ, Wang R (1994) Light dynamics of marine primary productivity and photosynthetic product structure. Acta Oceanol Sinica 16(5):85-91

Joint IR (1989) The reponse of picophytoplankton to light. In: Herring PJ, Campbell AK, Whitfield M, Maddock L (eds) Light and life in the sea. Cambridge University Press, Cambridge, p 105-114

Jumars PA, Penry DL, Daross DA, Perry MJ, Frost BW (1989) Closing the microbial loop: dissolved organic carbon pathway to heterotrophic bacteria from incomplete ingestion, digestion and absorption in animals. Deep-Sea Res 36: $483-495$

Lancelot C, Mathot S (1987) Dynamics of a Phaeocystis dominated spring bloom in Belgian coastal waters. I. Planktonic activities and related parameters. Mar Ecol Prog Ser 37: $239-248$

Larry HW, El-Sayed SZ (1987) Contribution of the net-, nanoand picoplankton to the phytoplankton standing crop and primary productivity in the Southern Ocean. J Plankton Res 9:973-994

Larsson U, Hagström \& (1982) Fractionated phytoplankton primary production, exudate release and bacterial production in Baltic eutrophicated gradient. Mar Biol 67: $57-70$

Li WKW (1994) Primary production of prochlorophytes, cyanobacteria, and eucaryotic ultraphytoplankton: measurements from flow cytometric sorting. Limnol Oceanogr 31 $169-175$

Liang HX (1997) Analysis of oceanographic condition in the Taiwan Strait during Summer 1994. In: Hong HS (ed) Oceanography in China, no. 7 China Ocean Press, Beijing, p 48-61

Linley EAS, Newell RC (1984) Estimates of bacterial growth yields on plant detritus. Bull Mar Sci 35:409-425

Liu ZL, Ning XR, Cai YM (1998) Distribution characteristics of size-fractionated chlorophyll $a$ and primary productivity in Beibu Gulf, China. Acta Oceanol Sinica 17(1):71-83

Malone TC (1980) Size fractionated primary productivity of marine phytoplankton. In: Falkowski PG (ed) Primary productivity in the sea. Plenum Press, New York, p 301-319

Middelboe M, Nielsen B, Søndergaard M (1992) Bacterial utilization of dissolved organic carbon (DOC) in coastal waters-determination of growth yield. Arch Hydrobiol
Beih Ergeb Limnol 37:51-61

Murphy LS, Haugen EM (1985) The distribution and abundance of phototrophic ultraplankton in the North Atlantic. Limnol Oceanogr $30: 47-58$

Ning XR, Vaulot D (1991) Abundance, characteristics and environmental controlling of cyanobacteria in Yangtze River estuary and the adjacent East China Sea. Acta Oceanol Sinica 13:552-559

Ning XR, Liu ZL, Shi JX, Zhu GH, Gong M (1993) Sizefractionated biomass and productivity of phytoplankton in Prydz Bay and the adjacent Indian Sector of the Southern Ocean during the austial summer 1990/1991 Korean J Polar Res 4(2):17-28

Ning XR, Liu ZL, Zhu GH, Shi JX (1996) Size-fractionated biomass and productivity of phytoplankton and particulate organic carbon in the Southern Ocean. Polar Biol 16: $1-11$

Norrman B, Zweifel VL (1995) Production and utilization of dissolved organic carbon during an experimental diatom bloom. Limnol Oceanogr 40:898-907

Parsons TR, Strickland JDH (1962) On the production of particulate organic carbon by heterotrophic processes in sea water. Deep-Sea Res 8:211-222

Parsons TR, Maita Y, Lalli CM (1984) A manual of chemical and biological methods for seawater analysis. Pergamon Press, Oxford, p 107-109, 115-122, 123-132

Platt T, Subba Rao DV, Irwin B (1983) Photosynthesis of picoplankton in the oligotrophic ocean. Nature 301:702-704

Ray RT, Haas LW, Sieracki ME (1989) Autotrophic picoplankton dynamics in a Chesapeake Bay sub-estuary. Mar Ecol Prog Ser 52:273-285

Rieman B, Sorensen HM, Bjornsen PK, Horsted SJ, Jensen LM, Nielsen TG, Søndergaard M (1990) Carbon budgets for the microbial food web in estuarine enclosures. Mar Ecol Prog Ser 65:159-170

Sherr EB, Sherr BF, Albright LJ (1987) Bacteria: link or sink? Science 235:88-89

Sournia A (1982) Is there a shade flora in the marine plankton? J Plankton Res 4:391-399

Stockner JG, Antia NJ (1986) Algal picoplankton from marine and freshwater ecosystems: a multidisciplinary perspective. Can J Fish Aquat Sci 43:2472-2503

Takahashi M, Bienfang PK (1983) Size structure of phytoplankton biomass and photosynthesis in subtropical Hawaian waters. Mar Biol 76:203-211

Wang HL, Huang BQ, Hong HS (1997) Size-fractionated productivity and nutrient dynamics of phytoplankton in subtropical coastal environments. Hydrobiol 352:97-106

Waterbury JB, Watson SW, Valois FS, Franks DG (1986) Biological and ecological characterization of the marine unicellular cyanobacterium Synechococcus. In: Platt T, Li WKW (eds) Photosynthetic picoplankton. Can Bull Fish Aquat Sci 214:71-120

Watson SW, Novitsky JA, Quinby HL, Valois FW (1977) Determination of bacterial number and biomass in the marine environment. Appl Environ Microbiol 33:940-947

Weisse T, Müller H, Pinto-Coelho RM, Schweizen A, Springmann D, Baldninger $G$ (1990) Response of the microbial loop to the phytoplankton spring bloom in a large prealpine lake. Limnol Oceanogr 35:781-794

Wood AM, Vaalen LMV (1990) Paradox lost? On the release of energy-rich compounds by phytoplankton. Mar Microb Food Webs 4:103-116

Wright RJ, Hobbie JE (1966) Use of glucose and acetate by bacteria and algae in aquatic ecosystems. Ecology 47:447-464

Wu LY, Ruan WQ, Chen L (1997a) The geochemical behavior of phosphorus in the Taiwan Strait, II, the supplementation and 
cycle of phosphorus. In: Hong HS (ed) Oceanography in China, no. 7. China Ocean Press, Beijing, p 107-114

Wu LY, Ruan WQ, Chen R (1997b) The geochemical behavior of phosphorus in the Taiwan Strait I, Main factors of influence on the distribution and variation of dissolved phosphorus. In: Hong HS (ed) Oceanography in China, no. 7. China Ocean Press, Beijing, p 97-106

Editorial responsibility: Otto Kinne (Editor),

Oldendorf/Luhe, Germany
Zheng AR, Li WQ, Chen M (1992) Study on the underestimation of the determination of primary productivity deduced from DOC released by phytoplankton. J Xiamen Uni (Natural Science) 31:408-412

Zlotnik I, Bubinsky Z (1989) The effect of light and temperature on DOC excretion by phytoplankton. Limnol Oceanogr $34: 831-839$

Submitted: July 22, 1998; Accepted: January 25, 1999

Proofs received from author(s): June 28, 1999 